\title{
BARCODING
}

\section{Conserved primers for DNA barcoding \\ historical and modern samples from New}

\section{Zealand and Antarctic Birds}

\author{
SELINA PATEL*, JOHN WAUGH†, CRAIG D MILLAR* and DAVID M LAMBERT $\dagger+$ \\ * Allan Wilson Centre for Molecular Ecology and Evolution, University of Auckland, Private \\ Bag 92019, Auckland, New Zealand, † Allan Wilson Centre for Molecular Ecology and \\ Evolution, Massey University, Private Bag 102904 NSMC, Auckland, New Zealand. $\ddagger$ Griffith \\ School of Environment and School of Biomolecular and Physical Sciences, Griffith
}

University, 170 Kessels Road, Qld 4111, Australia

\begin{abstract}
Our ability to DNA barcode the birds of the world is based on the effective amplification and sequencing of a 648 base pair (bp) region of the mitochondrial cytochrome $c$ oxidase (COI or cox1) gene. For many geographic regions the large numbers of vouchered specimens necessary for the construction of a DNA barcoding database have already been collected and are available in museums and other institutions. However, many of these specimens are old (>20 years) and are stored as either fixed study skins or dried skeletons. DNA extracted from such historical samples is typically degraded and, generally, only short DNA fragments can be recovered from such specimens making the recovery of the barcoding region as a single fragment difficult. We report two sets of conserved primers that allow the amplification of the entire DNA barcoding region in either three or five overlapping fragments. These primer sets allow the recovery of DNA barcodes from valuable historical specimens that in many cases are unique in that they are unable or unlikely to be collected again. We also report three new primers that in combination allow the effective amplification from modern samples of the entire DNA barcoding region as a single DNA fragment for 17 orders of Southern Hemisphere birds.
\end{abstract}


Keywords: DNA barcoding, COI, cox1, avian primers, 5'-tags, species identification Received XX February; revision accepted XX

\section{Introduction}

At the heart of DNA barcoding is the proposition that individuals can be rapidly and easily assigned to the species level using standardised DNA sequences from the mitochondrial genome (Hebert et al. 2003a; Hebert et al. 2003b). A considerable body of research has been carried out that provides support for this proposition and there is currently intense international interest in this area of research. Furthermore, it has been suggested that the DNA barcoding approach, if successful, will complement modern taxonomy while at the same time revolutionising the way we routinely identify species in the future (Hajibabaei et al. 2007).

The World's avian fauna has been identified as a good candidate to test the general applicability of DNA barcoding because birds have been extensively studied using a range of approaches including morphology, genetics and behaviour. This has resulted in a stable and mature taxonomy (Baker et al. 2009; Gill 2007). However, to date, the majority of DNA barcoding studies on birds have been conducted using modern samples from Northern Hemisphere species (Hebert et al. 2004; Kerr et al. 2007; Yoo et al. 2006). It remains to be seen whether DNA barcoding will accurately identify species from non-continental regions where biogeographic patterns, mutation and speciation rates may have been quite different (Moritz \& Cicero 2004).

New Zealand and the Antarctic have a distinctive avian fauna of moderate size (comprising of approximately 290 native or indigenous species) with a high level of endemism (Heather \& Robertson 2005). In order to establish a DNA barcode database of these birds it is necessary to have access to a large number of vouchered museum specimens and to effectively amplify and sequence the DNA barcoding region from samples obtained from these specimens.

A 648bp region at the 5' end of the mitochondrial gene cytochrome $c$ oxidase subunit 1 (COI or cox1) has been identified as the DNA barcoding region for most animal species, including birds (Hebert et al. 2003a; Hebert et al. 2004). Two types of samples are available from vouchered museum specimens, fresh or modern tissue (blood, feather or muscle that has been 
preserved at low temperatures or in ethanol) and historical specimens (usually study skins or skeletons). Although many museums now collect and preserve samples from vouchered specimens for biochemical and DNA analysis (Arctander \& Fjeldsa 1994; Seutin \& Boag 1991), this is a relatively recent practice. As a result, there are only a relatively small number of modern tissue samples available from vouchered specimens for New Zealand and Antarctic birds and this is likely to be the case for many regions worldwide. Furthermore, the collection of new or additional vouchered specimens is in many cases difficult, expensive and time consuming. The vast majority of historical specimens are older than 20 years in age and have not been preserved with DNA analyses in mind. Samples from these specimens typically produce highly degraded DNA (Lindahl 1993). The size of the DNA fragments recovered from historical samples depends on the preservation method, sample age and a number of environmental factors (Hofreiter et al. 2001). The degraded nature of the recovered DNA from historical samples makes it difficult to amplify a fragment larger than 300-400bp in length as well as resulting in low rates of amplification (Zimmermann et al. 2008).

There are a number of approaches used to tackle the problem of generating barcodes from historical museum specimens. Short or minimalist barcodes have been recovered by amplifying only a selected 100-200bp fragment of the originally proposed $\sim 650 \mathrm{bp}$ COI region. In a number of insect genera mini-barcodes have proved to be successful in identifying almost all species (Hajibabaei et al. 2006). However, mini-barcodes show limited success compared with the full-length barcode and only work within confined taxonomic groups (Hajibabaei et al. 2006). Although potentially useful for the identification of individual samples, this approach does not resolve the issue of having to construct an initial full-length database from which to make these identifications. Furthermore, whether it can be applied to avian species is yet to be determined.

Another approach is to use a range of DNA repair enzymes. These enzymes can increase the amplification success rate by repairing some of the damage that is induced in DNA as a result of chemical treatment or aging. The most common types of DNA damage to historical and ancient DNA are oxidative and hydrolytic damage (Hoss et al. 1996). Deamination, a type of hydrolytic damage common to cytosine residues, results in the replacement of cytosine with uracil, ending in $C$ to $T$ and $G$ to A transitions during PCR (Evans 2007). Treatment with DNA repair enzymes can result in the reversal of most types of DNA damage leading to higher amplification success rates (Evans 2007). However, this approach has a number of 
shortcomings specifically its inability to repair fragmented DNA and its high cost when processing large numbers of specimens.

The ability to recover DNA sequences from historical samples is in part dependent on the size of the PCR product targeted, generally the smaller the amplicon size the higher the rate of amplification success. Therefore, for any section of DNA, complete sequences can be recovered from historical samples by targeting a number of smaller overlapping regions. Once obtained, these overlapping fragments can be assembled and this approach has been used very successfully in the study of ancient DNA (Millar et al. 2008). Hence, the ability to DNA barcode the birds of the World will be facilitated by the availability of a set of conserved primers that will allow the amplification of the COI barcoding region from historical samples.

We report the development of two sets of PCR primers that reliably amplify from historical samples the COI barcoding region in three or five short segments. In addition, one of these primers, in combination with two others, also allows the effective amplification of the entire COI barcoding region as a single fragment from modern samples from 17 orders of Southern Hemisphere birds tested.

\section{Materials and Methods}

\section{Primer Design}

Primers for the amplification of historical and modern tissue were designed based on an alignment (using the Clustal $\mathrm{X}$ algorithm) of sequences obtained from New Zealand and Antarctic avian species in addition to a number of COI sequences available on GenBank (accession numbers available in supplementary data Table S1). Highly conserved regions were targeted as areas of interest for the synthesis of potential primers. Primer integrity was checked using Amplify 3X, available from http://engels.genetics.wisc.edu/amplify/ and NetPrimer available on the PREMIER biosoft International website www.premierbiosoft.com/netprimer/netprlaunch/netprlaunch.html 
Two sets of internal primers (Table 1) were designed to span the 648bp COI region for historical samples considered to have low quality DNA. The first primer set contained three primer pairs resulting in three overlapping fragments (average length 310bp; Fig. 1). The second primer set contained five primer pairs resulting in five shorter overlapping fragments (average length 190bp; Fig 1) to span the same 648bp region. Each internal primer contained a randomly generated $18 \mathrm{bp}$ tag attached to its 5 ' end in order to improve the sequencing of the resulting PCR products. Forward internal primers all contained an identical Ftag sequence and similarly all reverse internal primers contained an identical Rtag sequence. Internal primer pairs were tested on a range of modern samples represented from 15 avian orders prior to being used to amplify DNA from historical samples.

Three primers, one forward and two reverse were designed to amplify the entire 648bp COI region as a single fragment to be used for modern specimens. The forward primer, AWCF1 was also used as part of the primer set for historical samples. Primer pairs intended for modern specimens did not contain the 18bp tags. All primer sequences and their expected fragment lengths are shown in Table 1.

\section{DNA Extraction from historical and modern samples}

Historical specimens in the form of dried skins used for this study were obtained from Canterbury Museum (Christchurch, New Zealand). Until 1970 all specimens were preserved with arsenical soap. After this date the preservative used was changed to borax. Both methods are commonly used in museums worldwide. Preparation did not involve any special preservation on the legs and toe pads however. These were allowed to dry out naturally ( $\mathrm{P}$ Scofield 2009, pers. comm. 6 April,). All samples were collected from the foot and toe region of the specimens.

Between 5 and 64mg of tissue was used per extraction and all tissue was macerated with a sterile scalpel blade prior to extraction. DNA isolation from dried skins was performed using proteinase K/DTT/SDS digestion followed by a DNeasy tissue extraction kit for the post-lysis steps according to the manufacturer's instructions (Qiagen). Negative controls were included for each set of extractions. No more than five samples were extracted per set. All pre-PCR steps were carried out in a separate laboratory solely dedicated to ancient DNA work. DNA from modern samples (fresh tissue) was extracted in a different laboratory using a standard 
proteinase K digestion and a modified version of the phenol/chloroform method (Lawrence et al. 2008; Sambrook et al. 1989).

PCR amplification and Sequencing

PCRs were run in 25 $\mu \mathrm{l}$ volume reactions and included 1X PCR buffer (Invitrogen), 2.5mM $\mathrm{MgCl}_{2}, 1 \mathrm{mg} / \mathrm{ml} \mathrm{BSA}, 0.5 \mu \mathrm{M}$ forward and reverse primers, 4\% DMSO (only for 5'-tagged primers), $0.2 \mathrm{mM}$ dNTPs, $1 \mathrm{U}$ of Platinum Taq DNA polymerase (Invitrogen) and 3-4 $\mu \mathrm{l}$ of DNA template from the final elution for historical samples and 25-50ng of DNA for modern samples. The thermal cycling conditions for historical samples was as follows: 2 min at $94^{\circ} \mathrm{C}$ followed by 10 cycles of $20 \mathrm{~s}$ at $94^{\circ} \mathrm{C}, 20 \mathrm{~s}$ at $55^{\circ} \mathrm{C}$ and $20 \mathrm{~s}$ at $72^{\circ} \mathrm{C}$ followed in turn by 30 cycles of 20s at $94^{\circ} \mathrm{C}, 20$ s at $50^{\circ} \mathrm{C}$ and 20 s at $72^{\circ} \mathrm{C}$ and a final $4 \mathrm{~min}$ at $72^{\circ} \mathrm{C}$. In the case of modern samples the thermal cycling conditions were altered and consisted of 2 min at $94^{\circ} \mathrm{C}$ followed by 35 cycles of 30s at $94^{\circ} \mathrm{C}, 30$ s at $57.5^{\circ} \mathrm{C}$ and 30 s at $72^{\circ} \mathrm{C}$ and a final 4 min at $72^{\circ} \mathrm{C}$. PCR products were visualized on a $2 \%$ agarose gel. The remaining volume of PCR products were purified using the Agencourt AMPure PCR Purification system (Beckman Coulter). All purified PCR products were then cycle sequenced using Big Dye 3.1 chemistry and subsequently analysed on an ABI Prism 3130xl genetic analyzer. Sequencing was carried out bidirectionally to produce an overlap of at least 648bp of the COI region for all modern samples. In the case of the historical samples, three or five overlapping fragments were amplified which covered the same COI region. In each case, these fragments were bidirectionally sequenced from independent PCR reactions. Once the fragments were sequenced, the complete DNA barcode for each historical sample was assembled by concatenating sequences using the software programmes Sequencher 4.6 (Gene Codes Corporation) and Vector NTI (Invitrogen). Only those sequences which reached PHRED scores of 20 or above for at least $90 \%$ of individual bases were deemed acceptable.

\section{Results}

We designed and tested two sets of 5'-tagged PCR primers that reliably amplified short DNA fragments from historical samples for the barcoding region. The first set of primers containing three primer pairs generated three fragments approximately 310bp in size whereas the second set containing five primer pairs generated shorter fragments of approximately 
190bp in size. Both primer sets were first tested on a range of modern samples with representative species from 15 different orders (Table 2) prior to be being used on historical specimens. Of a total of 29 species, both primer sets worked on all species tested.

Twenty seven historical samples were utilized in this study belonging to nine different orders (See supporting information Table S2 for species list). The age of the historical specimens tested ranged from 16 to 115 years. PCR products were amplified at similar success rates from both the three and five primer pair sets for the same given samples tested suggesting that the three primer pair set is the best option (Table 2). The AWCF1/AWCR6 primer pair which amplifies the entire 648bp COI fragment was used as a control for historical specimens with no products being amplified.

Of the 27 historical samples tested, 16 samples successfully amplified the regions of interest resulting in an amplification success rate of 59\%. Further analysis found PCR success to be strongly correlated with specimen age. When separated into age groups we found samples which were 80 years or less in age had a higher average amplification success rate of $77 \%$ $(n=13)$ than their older counterparts of greater than 80 years of age which had an average amplification success rate of $50 \%(n=12)$. However there was no significance difference found between the two age groups (Fisher's exact test, $P$ value $=0.2262$ ). Two of the 27 samples were of unknown ages and could not be classified into age groups; neither produced positive PCR results.

Historical specimens belonging to the orders Anseriformes, Pelecaniformes and Psittaciformes did not successfully amplify the three fragments or the five fragments. However, their modern representatives were successfully amplified suggesting that the problem was due DNA damage rather than issues with primer binding. Bar one, all samples were over 80 years of age, stressing again the importance of age on PCR success. For the orders Charadriiformes and Anseriformes the last primer pair (AWCintF5/AWCintR6) posed a problem for some species. We were able to design an alternate primer pair (AWCintF6/AWCintR7) for these orders (refer to Table 1). This primer pair could have future use for other untested orders if a similar problem is encountered.

A number of previously described avian COI primers (Hebert et al. 2004; Kerr et al. 2009) designed to amplify a single fragment for modern samples from the Northern Hemisphere 
species had limited success when applied to samples from the New Zealand and Antarctic avifauna (data not shown). In particular, the amplification of DNA from tube nosed seabirds (Procellariformes) and kiwi (Apterygiformes) proved to be difficult. A similar result was found for the internal primers AvMiF1 and AvMiR1 where preliminary tests on Procellariformes resulted in the amplification of multiple fragments. This difficulty could be attributed to the fact that New Zealand and Antarctica have a more diverse and larger number of endemic seabirds than other geographic regions like North America for which these avian primers were originally designed. Moreover, orders like the Apterygiformes (kiwi) are unique to New Zealand.

The successful amplification of the entire barcoding region using the newly designed primers AWCF1, AWCR6 and AWCR3, are shown in Table 3. The only previously published avian primer to have applicability to New Zealand and Antarctic birds was the COIbirdR2 primer (Kerr et al. 2009) when paired with our AWCF1 primer. This primer pair worked extremely well for Passerines (Table 3). The newly designed AWCF1/AWCR6 primer pair worked well for most orders of birds, with the forward primer AWCF1 proving to be universally successful at binding appropriately and the main reverse primer AWCR6 proving to be highly successful in the majority of cases. AWCR3 worked well in species for which AWCR6 did not prove successful. AWCR3 worked particularly well in Apterygiformes, where all five species of this order could only be amplified with the AWCF1/AWCR3 primer pair.

The majority of the sequences generated using the AWCF1/AWCR3/AWCR6 fell into the category of high quality as stipulated by the Barcode of Life Data System (BOLD) where mean PHRED scores were $>40$ (Ratnasingham \& Hebert 2007).

\section{Discussion}

COI sequence variation between taxonomic groups has led to difficulties in the design of a single primer pair with universal applicability. Furthermore, in the case of historical samples, the 648bp COI barcoding region can only be recovered in smaller fragments requiring multiple primer sets leading to the proposition that primers must be customised to suit. However, the generation of taxa-specific primers is an impractical. A realistic solution to this problem is to generate a small set of primers that will work effectively on all avian species, 
both historical and modern. The primers generated by us are an example of such sets (Figure 1). These primers, designed to amplify the barcode region of historical and modern samples from New Zealand and Antarctic bird species proved generally successful with only a few exceptional taxa, such as the Apterygiformes requiring specialised primers. Since these primers were designed using an alignment of sequences from a range of both Northern and Southern Hemisphere species, it is likely that they will be effective for avian orders from many geographic locations. It is important to note that there are a number other primers published that are not tested in this study which could prove to be highly useful (Lohman et al. 2009; Tavares \& Baker 2008). However, our primers have a very broad applicability, having been tested on large number of species from 17 avian orders. All primers generated high quality sequences for the region of interest. Primers designed for modern samples had binding sites at least 80bp from the start and end of the barcode region to allow for good overlapping bi-directional sequence and to make allowance for the loss of sequence data which occurs at the beginning of each sequence read.

To maximise chances of obtaining amplifiable DNA from historical specimens we suggest sampling from the toe pad area where the risk of damage from preservatives is minimal. Specimen age should also be carefully considered and where possible, younger specimens should be selected for DNA analysis.

The 648bp barcode region for historical avian specimens can now be amplified using tagged internal primers as either three or five fragments, depending on the DNA quality of individual samples. We suggest using the set of primers containing three primer pairs since the likelihood of achieving success with the set of three primers pairs is the same as that from the set of five primer pairs. As our results demonstrate, if one set of internal primers does not prove successful the other set is unlikely to work either. In the event that not all overlapping fragments are amplified there is the added possibility of using one or more of these smaller fragments as a mini-barcode once this approach has be confirmed to work for avian taxa.

The addition of 5'-tags to each of the internal primers provides a number of advantages. Not only does it result in an increase in the read length of each sequence, thus allowing for better overlap of individual contigs, but it has been shown to greatly improve sequence quality (Binladen et al. 2007). This is crucial for historical samples where DNA damage is frequent. The 5'-tags also allow for large-scale sequencing as well as being more cost effective, as only 
two primers (forward and reverse tags) are required instead of the many individual forward and reverse primers.

The disadvantage, however, is that the processes of DNA extraction, PCR amplification and sequencing from historical specimens can be taxing and time consuming. Thus, modern specimens should be utilised for barcoding purposes wherever possible. We suggest using DNA barcodes generated from historical samples as a way of adding to an already existing database where there is a lack of their modern counterparts or for cases of rare and endangered species where sample collection is problematic.

There is now an onus upon museums and other institutions to ensure the storage of well preserved vouchered samples of as many species as possible, from which, high quality DNA can be extracted. The maintenance of such collections is increasingly being adopted around the world. However, until such time as these collections become comprehensive and for rare or now extinct species, study skins and bones provide the only vouchered source of DNA. While that is the case, there is a need for methods, such as those outlined above, to provide a means of generating DNA barcodes.

\section{Acknowledgements}

Funding for this study was provided by the University of Auckland's Vice Chancellor's Development Fund and the Allan Wilson Centre for Molecular Ecology and Evolution. We would like to thank Leon Huynen for help with primer design and invaluable advice on ancient DNA techniques and also Judith Robbins for allowing us to make use of the Department of Anthropology ancient DNA Laboratory at the University of Auckland. We would like to thank all the people who kindly donated samples to make this study possible and in particular Paul Scofield for providing us with all the historical specimens from Canterbury museum. 
Fig. 1 A diagrammatic representation of the COI barcoding region used for birds with the relative position of the primers (triangles) indicated for amplifying historical and modern samples. The three black triangles and the two black bars indicate the combination of primers used and DNA fragments generated for modern samples. Similarly, the grey or white triangles and the grey or white bars represent the primer combinations and resulting DNA fragments generated for historical samples. The position of each primer and the amplified DNA fragments are given relative to the chicken mitochondrial genome. 
Arctander P, Fjeldsa J (1994) Avian tissue collections for DNA analysis. Ibis 136, 359360.

Baker AJ, Tavares ES, Elbourne RF (2009) Countering criticisms of single mitochondrial DNA gene barcoding in birds. Molecular Ecology Resources 9, 257268.

Binladen J, Thomas M, Gilbert P, Campos PF, Eska W (2007) 5'-Tailed sequencing primers improve sequencing quality of PCR products. BioTechniques 42, 174176.

Evans T (2007) DNA damage. NEB expressions 2.1, 1-3.

Gill FB (2007) Ornithology, 3rd edn. W.H. Freeman, New York.

Hajibabaei M, Singer GAC, Hebert PDN, Hickey DA (2007) DNA barcoding: how it complements taxonomy, molecular phylogenetics and population genetics. Trends in Genetics 23, 167-172.

Hajibabaei M, Smith AM, Janzen DH, et al. (2006) A minimalist barcode can identify a specimen whose DNA is degraded. Molecular Ecology Notes 6, 959-964.

Heather BD, Robertson HA (2005) The Field Guide to the Birds of New Zealand, Rev. edn. Penguin Books, Auckland

Hebert PDN, Cywinska A, Ball SL, deWaard JR (2003a) Biological identifications through DNA barcodes. Proceedings of the Royal Society of London. Series B: Biological Sciences 270, 313-321.

Hebert PDN, Ratnasingham S, de Waard JR (2003b) Barcoding animal life: cytochrome c oxidase subunit 1 divergences among closely related species. Proceedings of the Royal Society of London. Series B: Biological Sciences 270, S96-S99.

Hebert PDN, Stoeckle MY, Zemlak TS, Francis CM (2004) Identification of Birds through DNA Barcodes. PLoS Biology 2, 1657-1663.

Hofreiter M, Serre D, Poinar HN, Kuch M, Paabo S (2001) Ancient DNA. Nature Reviews Genetics 2, 353-359.

Hoss M, Jaruga P, Zastawny TH, Dizdaroglu M, Paabo S (1996) DNA damage and DNA sequence retrieval from ancient tissues. Nucleic Acids Research 24, 1304-1307.

Kerr KCR, Lijtmaer DA, Barreira AS, Hebert PDN, Tubaro PL (2009) Probing Evolutionary Patterns in Neotropical Birds through DNA Barcodes. PLoS ONE 4, e4379.

Kerr KCR, Stoeckle MY, Dove CJ, et al. (2007) Comprehensive DNA barcode coverage of North American birds. Molecular Ecology Notes 7, 535-543.

Lawrence HA, Taylor GA, Millar CD, Lambert DM (2008) High mitochondrial and nuclear genetic diversity in the world's most endangered seabird, the Chatham Island Taiko (Pterodroma magentae). Conservation Genetics 9, 1293-1301.

Lindahl T (1993) Instability and decay of the primary structure of DNA. Nature 362, 709-715.

Lohman DJ, Prawiradilaga DM, Meier R (2009) Improved COI barcoding primers for Southeast Asian perching birds (Aves: Passeriformes). Molecular Ecology Resources 9, 37-40.

Millar CD, Huynen L, Subramanian S, Mohandesan E, Lambert DM (2008) New developments in ancient genomics. Trends in Ecology \& Evolution 23, 386-393.

Moritz C, Cicero C (2004) DNA Barcoding: Promise and Pitfalls. PLoS Biology 2, 15291529.

Ratnasingham S, Hebert PDN (2007) bold: The Barcode of Life Data System. Molecular Ecology Notes 7, 355-364. 
Sambrook J, Fritsch EF, Maniatis T (1989) Molecular cloning : a laboratory manual Cold Spring Harbor Laboratory Press, New York.

Seutin GW, Bradley N, Boag PT (1991) Preservation of avian blood and tissue samples for DNA analyses. Canadian Journal of Zoology 69, 82-90.

Tavares E, Baker A (2008) Single mitochondrial gene barcodes reliably identify sisterspecies in diverse clades of birds. BMC Evolutionary Biology 8, 81.

Yoo H, Eah J, Kim J, et al. (2006) DNA Barcoding Korean Birds. Molecules and Cells 22, 323-327.

Zimmermann J, Hajibabaei M, Blackburn D, et al. (2008) DNA damage in preserved specimens and tissue samples: a molecular assessment. Frontiers in Zoology 5, 18. 


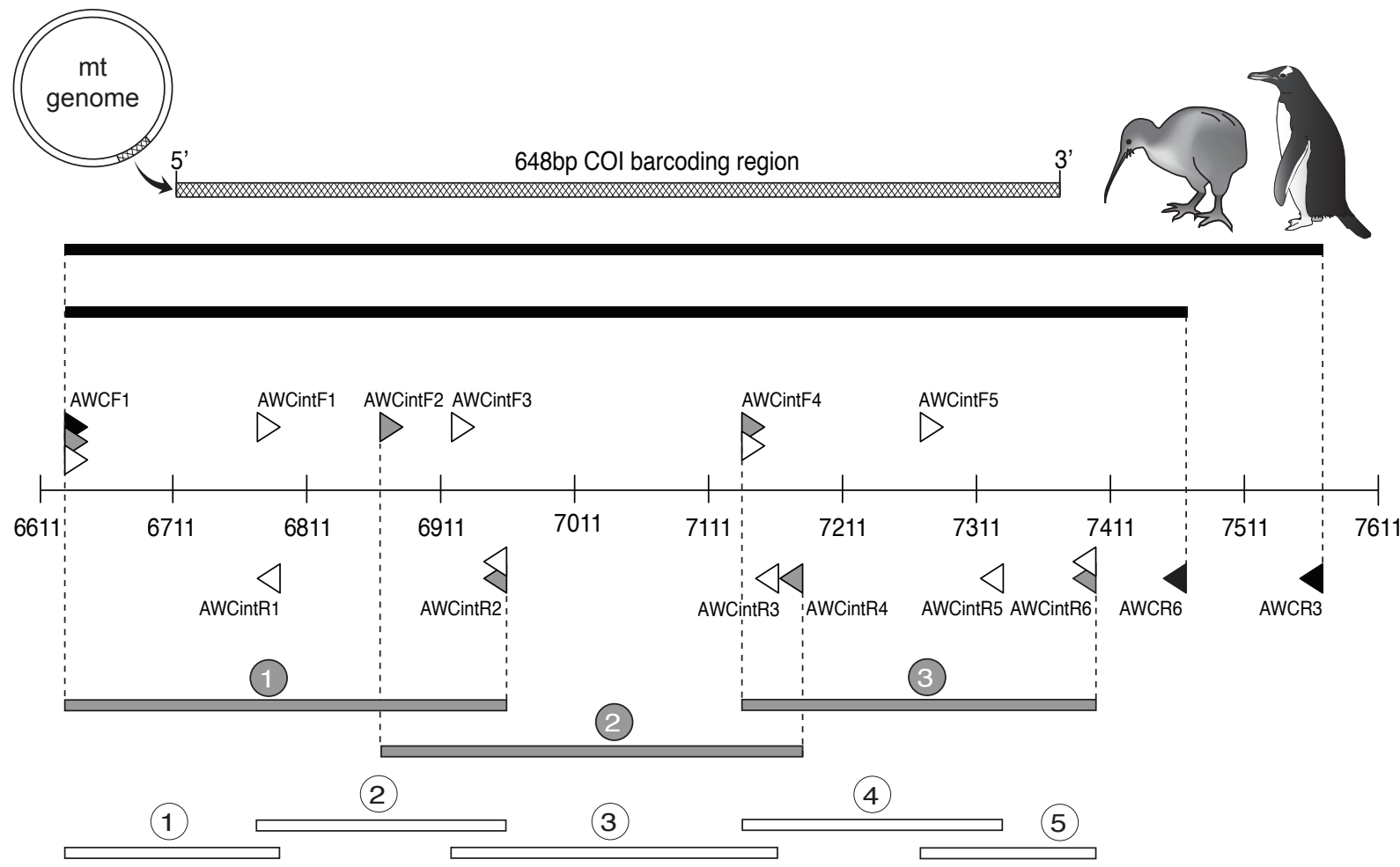


Table 1 PCR primers and 5'-tags used for the amplification of the 648bp COI region as either one, three or five fragments. The position of each primer is given relative to the chicken mitochondrial sequence. The 5'-tags were only added to the individual primers when PCR amplifying and sequencing ancient samples as either three or five fragments. AWCintF6 and AWCintR7 represent alternate primer pairs used for the orders Charadriiformes and Anseriformes.

\begin{tabular}{|c|c|c|c|c|c|c|}
\hline $\begin{array}{l}\text { Forward } \\
\text { Primer }\end{array}$ & Sequence 5' to 3' & $\begin{array}{l}\text { Position } \\
\text { (bp )* }\end{array}$ & $\begin{array}{l}\text { Reverse } \\
\text { Primer }\end{array}$ & Sequence 5' to 3' & $\begin{array}{l}\text { Position } \\
\text { (bp )* }\end{array}$ & $\begin{array}{l}\text { Fragment } \\
\text { Size (bp )* }\end{array}$ \\
\hline & Primers for modern samples & & & & & \\
\hline AWCF1 & CGCYTWAACAYTCYGCCATCTTACC & $6625-6649$ & AWCR6 & ATTCCTATGTAGCCGAATGGTTCTTT & 7446-7471 & 848 \\
\hline \multirow[t]{2}{*}{ AWCF1 } & & & AWCR3 & ATGCTCGGGTGTCTACGTCTAT & $7542-7563$ & 936 \\
\hline & \multirow{2}{*}{\multicolumn{2}{|c|}{ First set of internal primers containing 3 primer pairs }} & & & & \\
\hline AWCF1 & & & AWCintR2 & ATGTTGTTTATGAGTGGGAATGCTATG & & 328 \\
\hline AWCintF2 & ATCGGAGCCCCAGACATAGCATT & $6912-6934$ & AWCintR4 & TTGATGGCTGTTGTGATAAAGTTGAT & 7137-7162 & 314 \\
\hline \multirow[t]{2}{*}{$\mathrm{AWCintF}^{\dagger}$} & TССТСАATCCTGGGAGCAATCAACTT & 7119-7144 & AWCintR6 $^{\ddagger}$ & GGATTAGGATGTAGACTTCTGGGTG & 7371-7395 & 278 \\
\hline & Second set of internal primers containing $5 p$ & rimer pairs & & & & \\
\hline AWCF1 & & & AWCintR1 & CCTGGTTGACCTAGTTCTGCTCG & $6765-6787$ & 163 \\
\hline AWCintF1 & CCGAGCAGAACTACGTCAACC & $6764-6784$ & AWCintR2 & & 6926-6952 & 189 \\
\hline AWCintF3 & ATAATCGGAGGCTTCGGAAACTGA & $6873-6896$ & AWCintR3 & TGGGAKAGGGCTGGTGGTTTTATGTT & 7161-7186 & 251 \\
\hline AWCintF $4^{\dagger}$ & & & AWCintR5 & TGCTGGGTCGAAGAATGTGGTGTT & 7299-7322 & 204 \\
\hline \multirow[t]{2}{*}{ AWCintF5 } & GGCATCACCATACTACTAACAGACCG & 7266-7291 & AWCintR6 $^{\ddagger}$ & & & 130 \\
\hline & 5'tags for internal primers & & & & & \\
\hline Ftag & AGTCGACGCTTCTAGCTT & - & Rtag & CATGCTACCTGCTACTGT & - & \\
\hline
\end{tabular}


Table 2 Results of PCR success of modern and historical samples for the two primer sets designed to amplify DNA from historical specimens. PCR success is defined as fragments amplified ( $\mathrm{Y}$ = amplified; $\mathrm{N}=$ not amplified; $\mathrm{NT}$ = not tested).

\begin{tabular}{|c|c|c|c|c|c|c|}
\hline \multirow[b]{2}{*}{ Order } & \multicolumn{3}{|c|}{ Modern Specimens } & \multicolumn{3}{|c|}{ Historical Specimens } \\
\hline & $\begin{array}{l}3 \\
\text { fragments }\end{array}$ & $\begin{array}{l}5 \\
\text { fragments }\end{array}$ & $\begin{array}{l}\text { No. of } \\
\text { Species }\end{array}$ & $\begin{array}{l}3 \\
\text { fragments }\end{array}$ & $\begin{array}{l}5 \\
\text { fragments }\end{array}$ & $\begin{array}{l}\text { No. of } \\
\text { Species }\end{array}$ \\
\hline Anseriformes & $\mathrm{Y}^{*}$ & $\mathrm{Y}^{*}$ & 2 & $\mathrm{~N}$ & $\mathrm{~N}$ & $0 / 2$ \\
\hline Ciconiiformes & $\mathrm{Y}$ & $\mathrm{Y}$ & 2 & $\mathrm{Y}$ & $\mathrm{Y}$ & $2 / 2$ \\
\hline Charadriiformes & $\mathrm{Y}^{*}$ & $\mathrm{Y}^{*}$ & 2 & $\mathrm{Y}^{*}$ & $\mathrm{Y}^{*}$ & $2 / 4$ \\
\hline Falconiformes & $\mathrm{Y}$ & $\mathrm{Y}$ & 2 & $\mathrm{Y}$ & $\mathrm{Y}$ & $1 / 2$ \\
\hline Gruiformes & $\mathrm{Y}$ & $\mathrm{Y}$ & 2 & $\mathrm{Y}$ & $\mathrm{Y}$ & $1 / 2$ \\
\hline Pelecaniformes & Y & $\mathrm{Y}$ & 2 & $\mathrm{~N}$ & $\mathrm{~N}$ & $0 / 2$ \\
\hline Procellariformes & $\mathrm{Y}$ & $\mathrm{Y}$ & 2 & $\mathrm{Y}$ & $\mathrm{Y}$ & $9 / 10$ \\
\hline Sphenisciformes & $\mathrm{Y}$ & $\mathrm{Y}$ & 2 & $\mathrm{Y}$ & $\mathrm{Y}$ & $1 / 2$ \\
\hline Psittaciformes & $\mathrm{Y}$ & $\mathrm{Y}$ & 2 & $\mathrm{~N}$ & $\mathrm{~N}$ & $0 / 1$ \\
\hline Passeriformes & $\mathrm{Y}$ & $\mathrm{Y}$ & 2 & NT & NT & - \\
\hline Apterygiformes & Y & $\mathrm{Y}$ & 2 & NT & NT & - \\
\hline Coraciiformes & $\mathrm{Y}$ & $\mathrm{Y}$ & 2 & NT & NT & - \\
\hline Galliformes & $\mathrm{Y}$ & $\mathrm{Y}$ & 2 & NT & NT & - \\
\hline Columbiformes & $\mathrm{Y}$ & $\mathrm{Y}$ & 2 & NT & NT & - \\
\hline Podcipediformes & $\mathrm{Y}$ & $\mathrm{Y}$ & 1 & NT & NT & - \\
\hline
\end{tabular}


Table 3 PCR primer success on 17 different avian orders. The numbers represent the species of each order from which the target sequence was successfully amplified, using different combinations of PCR primers.

\begin{tabular}{llllll}
\hline Order & AWCF1/R6 & AWCF1/R3 & $\begin{array}{l}\text { AWCF1/R6 } \\
\text { \& AWCR3 }\end{array}$ & $\begin{array}{l}\text { AWCF1/ } \\
\text { COIbirdR2 }\end{array}$ & $\begin{array}{l}\text { No. of species per } \\
\text { order }\end{array}$ \\
\hline Anseriformes & 16 & - & - & 1 & 16 \\
Apterygiformes & - & 5 & - & - & 5 \\
Charadriiformes & 25 & 4 & 4 & 1 & 25 \\
Ciconiiformes & 9 & - & - & 2 & 9 \\
Columbiformes & 3 & - & - & 3 & 3 \\
Coraciiformes & 1 & - & - & 1 & 1 \\
Cuculiformes & 2 & - & - & - & 2 \\
Falconiformes & 2 & - & - & 1 & 2 \\
Galliformes & 1 & - & - & 1 & 1 \\
Gruiformes & 7 & 3 & 2 & 4 & 8 \\
Passeriformes & 17 & 6 & 1 & 20 & 20 \\
Pelecaniformes & 7 & 2 & - & - & 7 \\
Podcipediformes & 1 & 2 & - & - & 3 \\
Procellariformes & 33 & 5 & 3 & 5 & 35 \\
Psittaciformes & 4 & 3 & 2 & 1 & 5 \\
Sphenisciformes & 6 & 1 & 1 & 1 & 6 \\
Strigiformes & 1 & 1 & 1 & - & 1 \\
Total & $\mathbf{1 3 5}$ & $\mathbf{3 2}$ & $\mathbf{1 4}$ & $\mathbf{4 1}$ & $\mathbf{1 4 9}$ \\
\hline
\end{tabular}




\section{Supporting Information for online publication only}

Table S1 Accession numbers of species used as part of the alignment for primer design

\begin{tabular}{|c|c|}
\hline Scientific Name & Accession Number \\
\hline Anas clypeata & AY666352 \\
\hline Anas platyrhynchos & AY666490 \\
\hline Branta canadensis & DQ019124 \\
\hline Arenaria interpes & AY074885 \\
\hline Bartramia longicauda & AY666283 \\
\hline Calidris alba & AY666377 \\
\hline Calidris fuscicollis & AY666305 \\
\hline Calidris mauri & AY666261 \\
\hline Calidris minutilla & AY666272 \\
\hline Larus dominicanus & AY293619 \\
\hline Limosa haemastica & AY666302 \\
\hline Pluvialis dominica & AY666317 \\
\hline Pluvialis squatarola & AY666202 \\
\hline Tringa flavipes & AY666309 \\
\hline Egretta novaehollandiae & DQ780878 \\
\hline Nycticorax caledonicus & AY666336 \\
\hline Eurystomus orientalis & AF407486 \\
\hline Chrysococcyx lucidus & AF168062 \\
\hline Alectoris chukar & AY666409 \\
\hline Callipepla californica & AY666478 \\
\hline Colinus virginianus & AY666347 \\
\hline Numida meleagris & AP005595 \\
\hline Phasianus colchicus & AY666332 \\
\hline Acanthisitta chloris & AY325307 \\
\hline Acridotheres tristis & AY666184 \\
\hline Carduelis flammea & AY666474 \\
\hline Corvus frugilegus & Y18522 \\
\hline Gymnorhina tibican & AF197868 \\
\hline Passer domesticus & AY666316 \\
\hline Pelecanus conspicillatus & DQ780883 \\
\hline Phaethon rubricauda & AP009043 \\
\hline Podiceps cristatus & AP009194 \\
\hline Pterodroma brevirostris & AY158678 \\
\hline Oceanodroma leucorhoa & AY666284 \\
\hline Procellaria cinerea & AP009191 \\
\hline Thalassarche chrysostoma & AP009193 \\
\hline Thalassarche melanophris & AY158677 \\
\hline Strigops habroptilus & AY309456 \\
\hline Eudyptes chrysocome & AP009189 \\
\hline Eudyptula minor & AF362763 \\
\hline Ninox nvaeseelandiae & AY309457 \\
\hline Apteryx australis & AF338708 \\
\hline Apteryx haastii & AY016010 \\
\hline Apteryx mantelli & AY016010 \\
\hline
\end{tabular}


Table S2 List of historical specimens from Canterbury museum

\begin{tabular}{lll}
\hline Scientific Name & Museum Voucher ID & Collection Date (Year) \\
\hline Daption capensis & Av 1212 & 1938 \\
Stictocarbo punctatus & Av 649 & 1929 \\
Gallirallus australis & Av 1678 & 1894 \\
Falco novaeseelandiae & Av 1619 & 1923 \\
Botaurus poiciloptilus & Av 17449 & 1958 \\
Oceanites nereis & Av 36790 & 1987 \\
Pelecanoides urinatrix & Av 512 & 1929 \\
Cyanomorphus auriceps & Av 50 & 1895 \\
Pterodroma macroptera & Av 1176 & 1928 \\
Hymenolaimus malacorhynchos & Av 2961 & 1993 \\
Anas gracilis & Av 2998 & - \\
Charadrius obscurus & Av 2478 & 1922 \\
Sterna caspia & Av 1896 & 1944 \\
Eudyptes scalteri & Av 809 & 1923 \\
Himantopus himantopus & Av 682 & - \\
Micronectes giganteus & Av 2295 & 1939 \\
Leucocarbo carunculatus & Av 655 & 1925 \\
Egretta sacra & Av 659 & 1915 \\
Falco novaeseelandiae & Av 527 & 1913 \\
Porzana pusilla & Av 1654 & 1935 \\
Pterodroma macroptera & Av 418 & 1929 \\
Diomedea epomophora & Av 19580 & 1963 \\
Oceanites nereis & Av 1302 & 1949 \\
Himantopus ostralegus & Av 688 & 1909 \\
Eudyptula minor & Av 822 & 1923 \\
Fregata tropica & Av 502 & 1929 \\
Pterodroma cervicalis & Av 1313 & 1914 \\
\hline
\end{tabular}

